\title{
Sexual Abuse Whirlpool: Characteristics of Abuse (Type, Perpetrator-Victim Relation, Psychological Reactions of Victims), Parents' Attitudes and Behaviours of Abusers (Grooming Methods)
}

\author{
Cinsel Istismar Girdabı: İstismarın Özellikleri (Tipi, Fail-Mağdur Yakınlığı, Mağdurların \\ Psikolojik Tepkileri), Ebeveynlerin Tutumları ve İstismarcıların Davranışları \\ (Grooming Metotları)
}

\author{
(D) Burak Miraç Gönültaş Assoc. Prof. \\ Sivas Cumhuriyet University, Faculty of Letters, Department of Social Work, Sivas, Turkey
}

\section{ABSTRACT}

Objective: This study aims to analyze $(n=175)$ sexual abuse cases conducted in Istanbul between 2009 and 2012 by making use of a qualitative method and to describe characteristics of the cases, the attitudes of the parents and the methods of grooming of the abusers by making a holistic assessment.

Methods: Qualitative analysis method was used in this study. For the data, the document analysis procedure according to the journal article reporting standards for qualitative research (JARS-Qual) standards and the research design recommended by the American Psychological Association were followed. A coding table was constructed and data were analyzed through coding table.

Results: The victims $(n=202)$ were mostly girls and the average age was 11.4 years. They were mostly exposed to penetration-related abuse (52\%). The abusers were mostly from intimates of the victim (57\%). Most of the abuses took place at the perpetrator's home or in a place he/ she knew (65.8\%). The majority of parents learned about the abuse during the investigation (56\%). Abusers applied methods such as promises, bribes, threats, or coercion to approach children and become physically closest. Bribes, warnings and threats were used to prevent the child from disclosing it after the abuse (70\%).

Conclusion: Children appear to be quite vulnerable due to a number of circumstances before and after the case of abuse. This vulnerability leads them to be exposed into the act of abuse, and prevents them from disclosing the abuse. The conditions leading to vulnerability have been assessed as a whole and defined as a "sexual abuse whirlpool".

Keywords: Sexual abuse, victim, child, parents, abusers, grooming methods

Address for Correspondence/Yazıșma Adresi: Burak Miraç Gönültaş Assoc. Prof., Sivas Cumhuriyet University, Faculty of Letters, Department of Social Work, Sivas, Turkey

E-mail: mburakgonultas@gmail.com

ORCID ID: orcid.org/0000-0001-9132-1464
Received/Geliș tarihi: 20.08.2020 Accepted/Kabul tarihi: 21.09.2020

\footnotetext{
(c) Copyright 2021 by the The Association of Forensic Medicine Specialists / The Bulletin of Legal Medicine published by Galenos Publishing House

(CTelif Hakkı 2021 Adli Tıp Uzmanları Derneği / Adli Tıp Bülteni, Galenos Yayınevi tarafından yayınlanmıştır.
} 


\section{öz}

Amaç: Bu çalışma niteliksel bir yöntemle i̇stanbul'da 2009-2012 yılları arasında gerçekleşmiş 175 cinsel istismar olgusunu analiz etmeyi, olgunun özelliklerini, ebeveynlerin tutumlarını ve istismarcıların çocuklara yaklaşma yöntemlerini betimleyerek, istismar mağduru çocuk açısından bütüncül bir durum tespiti yapmayı ve bu çerçevede öneriler sunmayı amaçlamaktadır.

Yöntem: Çalışmada nitel analiz yöntemi tercih edilmiştir. Çalışmanın verileri için nitel araştırma için dergi makale raporlama standartları (JARSQual) standartlarına göre belge analizi prosedürü ve Amerikan Psikoloji Derneği tarafından önerilen araştırma tasarımı takip edilmiştir. Bir kodlama tablosu oluşturularak veriler analiz edilmiş ve frekans ve yüzdelik dağılımları rapor edilmiștir.

Bulgular: Mağdurlar (n=202) en fazla kız çocuğu idi ve yaş ortalaması 11,4 yıl idi. En çok penetrasyon içerikli istismara maruz kalmışlardır (\%52). İstismarcılar çoğunlukla mağdurun tanıdığı çevredendir (\%57). İstismarlar en çok failin evi ya da bildiği bir yerde gerçekleșmiștir (\%65,8). Ebeveynlerin çoğunluğu istismarı soruşturma sırasında öğrenmiştir (\%56). Çocuğuna inanmama veya iddia edilen kişinin böyle bir şey yaptığına inanmama durumuna rastlanmıştır (\%22). İstismarcılar çocuklara yaklaşmak ve fiziksel olarak en yakın hale gelmek için vaat, rüşvet, tehdit, zorlama gibi yöntemlere başvurmuşlardır (\%56). Bazı failler tehdit ve zorlama ile doğrudan, bazıları ise daha stratejik yöntemlerle çocuğa en yakın hale gelmiştir. İstismar sonrası çocuğun ifșa etmemesi için rüșvet, tembih ve tehdide bașvurulmuştur (\%70'e yakın).

Sonuç: Cinsel istismar mağduru çocukların istismar olgusunun öncesinde ve sonrasında birtakım koșullara bağlı olarak oldukça savunmasız oldukları görülmektedir. Bu savunmasızlık onların istismar eylemine sürüklenmelerine yol açmakta, sonrasında ise yașadıkları istismarı ifşa etmelerini engellemektedir. Savunmasızlığa sebep olan koşullar bir bütün olarak değerlendirilmiş ve "cinsel istismar girdabı" olarak tanımlanmıştır.

Anahtar Kelimeler: Cinsel istismar, mağdur, çocuk, ebeveyn, istismarcı, grooming metotları

\section{INTRODUCTION}

Sexual abuse is the most difficult type of child abuses in terms of disclosure and investigation (1,2). Children are very important for their family and society in terms of their short and longterm effects on them. According to the studies conducted on sexual abuse, the prevalence of sexual abuse is much higher than it appears $(3,4)$. It is thought that one fifth of girls and one tenth of boys are subjected to sexual violence (5). According to the results of the study investigating the prevalence of sexual abuse in different countries, the reporting of sexual abuse is between $7-36 \%$ for women and 3-29\% for men (6). In a similar vein, in a study carried out with 1955 female secondary school students in Istanbul, $13.4 \%(n=250)$ of 1,871 , who accepted to take part in the interview, reported that they were sexually abused. According to the study, $11.3 \%$ of the children stated that they were exposed to disturbing sexual touch, $4.9 \%$ were forced to have sexual intercourse by using force, and $3 \%$ were victims of both forms of abuse (7). The prevalence and occurrence of sexual abuse are among the main factors affecting the detection and investigation of sexual abuse.

According to the studies on sexual abuse, the risk of being a victim increases as children get older $(8,9)$. Although age varies widely in each reported abuse, the most common age range is between 8 and 14 years $(10,11)$. In regard to the studies on sexual abuse cases, in some studies, types of abuse involving penetration are more common than other types, but the reverse may occur $(12,13)$. With reference to the relevant literature, penetration prevalence findings in sexual abuse are between $0.8 \%$ and $31.9 \%$ (14). In terms of perpetrator-victim relation, the perpetrators are generally known by the victims, considering the relevant literature $(15,16)$. However, in some studies, the rate of abusers from extrafamilial (e.g. strangers) is higher (17). The impacts of sexual abuse on children's mental lives are negative. These impacts can lead to serious problems in the children's lives in the short and long terms $(18,19)$. Reactions may differ depending on the type of abuse, the relation of the victim-perpetrator, and whether the child is threatened after the abuse or not. These reactions can range from impaired emotional and sexual development, low self-confidence, increased fear and anxiety reactions, psychosomatic reactions, insecurity, sleeping problems, post-traumatic stress disorders, substance abuse, running away from home to suicidal behaviours (20-23).

The position of parents is crucial in abuse cases. It is often unexpected for a person to learn that his/her child is a victim of sexual abuse and is a complicated situation for him/her. Rejection, disbelief, and many different emotions can be felt by the parents. Firstly, the alleged suspects' refusal to admit the abuse and very rarely physical and medical evidence (24) or lack of witnesses are important factors in families' reactions like these. Secondly, sexual abuses, most of which happen at the hands of close relatives known by children (25) and especially families' disbelief in the possibility of the fact that people whom they are entrusted to commit such a crime are other factors explaining families' reactions given above. Therefore, at first, when the victim reports abuse, there may be situations such as the parents not believing the child, not supporting the child, and not taking protective measures. In a study, $65 \%$ of the mothers found the reports made within the first hour after the abuse credible (26). According to other studies, $69-78 \%$ of mothers found the reports partially or completely convincing (27). 
The perpetrators of sexual abuse are heterogeneous, but the rate of males is higher in general. Taking into consideration sexual abusers' approach tactics towards victims, related studies focus on perpetrators' grooming methods (28). Grooming methods contain a number of deceptive methods that seem innocent (such as making friends) in order for abusers to engage in sexual activity with children, thus making the victim obey and become unresponsive. The abusers approach children by means of these methods, break their resistance and manage to take them under control $(29,30)$. In addition, these enable the victim to remain silent after the abuse and may again lead the child to be abused (31). Behaviours such as threats and coercion lead children to be under control and desensitised, just like the methods of persuasion and deceit (28). Common grooming methods are deception, bribery, making promises, complimenting, manipulating, threat, and coercion (28-32). These methods help perpetrators to prepare the child for abuse. Studies on sexual abuse have considerably increased in our country in recent years. However, these studies do not deal with these cases as a whole in terms of the case-victimparent- perpetrator line. The purpose of this study is to analyze sexual abuse cases by using a qualitative method and make a holistic assessment from the abused children' eye by means of describing characteristics of the cases, the attitudes of the parents and the methods of approaching children by abusers. Within this framework, this study also aims to make some suggestions within this framework.

\section{MATERIALS and METHODS}

In this study, qualitative analysis method was preferred in order to see the pre processes of sexual abuse case, the moment of sexual abuse case and post processes of sexual abuse cases in more detail and in depth. It has been stated that qualitative research provides rich information for such studies (33). The document analysis procedure according to the Journal Article Reporting Standards for Qualitative Research standards and the research design recommended by the American Psychological Association were followed to collect the data of the present study (34). The reason lying behind choosing the document analysis is to prevent the psychological trauma that can be given to the victims of sexual abuse, and to protect them from subsequent secondary victimization while meeting them again. At that point, the documents with the judicial reports of the child victims of sexual abuse and other related parties (such as parents' statements) were made use of in this study. According to the report of the American Academy of Pediatrics Committee on Child Abuse and neglect (35), the statements of children who are the victims of abuse are of critical importance both in understanding the progression of the crime and in determining the legal and rehabilitative interventions to be determined for children. Content analysis was carried out and the frequency of the abusers' behaviours from the perspective of victims, parents and victims in the sample documents were analyzed by measuring. When the data analysed by means of the content analysis were reported, the subcategory "no information" was added to the main categories for which there was no information despite the expert inquiries. Collected data were analyzed, and the levels of frequency were reported.

\section{Sample Selection}

Sexual abuse files, which were investigated by the Istanbul Juvenile Office between 2009-2012, were selected as the sample of this study $(n=175)$, considering the permission granted for the data. The Criminal Investigation Unit of the Juvenile Office is a special unit, generally specialized in qualified sexual abuse investigations. Each investigation file includes crime investigation reports, doctor and expert reports, victim reports, reports of victims' relatives and suspects' statements (18). The number of victim reports received from 175 files is 202 (some cases have more than one victim). Victim reports are legal documents that victims of abuse report under the supervision of social workers (psychologists and social workers), lawyers and expert investigators in accordance with forensic interview techniques.

The reports are first recorded on camera by expert and trained investigators in the presence of social workers and lawyers, and then recorded and written as told by the victim (18). Reports are recorded as conveyed by children. Permission were gotten from Governance of Istanbul for cases.

Since the data were collected from the archive, permission was not obtained from the parties to the investigation because consent is not required in retrospective studies from archives (36). According to the rules of the Socio-Legal Studies Association (37), even if the data were obtained from the archive, adhering to the principle of confidentiality and anonymity, the names and personal information of the individuals were obscured during the analysis and no identifying information was added to the person. In addition, the documents containing the data were kept in a box belonging to the researcher that no one can reach.

\section{Data Collection}

The investigation documents as the sample were read by the researcher and another expert, and a code book was constituted. The researcher is a forensic science specialist and has the experience of investigation while the other expert is from the field of forensic psychology. Both experts randomly identified documents and read them for the code book. The determined main and sub categories were discussed and compared mutually in order to reach a consensus. In the last evaluation, there was $\% 87$ agreement between two experts. This rate is sufficient as stated by Miles and Huberman (38) (Table 1). 


\section{RESULTS}

\section{Cases and Victims}

The victims are mostly girls, their average age is 11.4 [minimum (min): 4, maximum (max): 14, standard deviation (SD): 2.22]. Victims have been exposed to forms of abuse: Non-touch forms (Sexual gaze, sexual talk, exhibitionism, making the victims watch pornography, and clothing), touch forms (touching, stroking, and kissing), and penetrating forms (vaginal penetration, anal penetration, oral penetration, and objectfinger insertion into body cavity). Among these, the victims have been exposed to the penetrating forms mostly. From the point of view of the victim-perpetrator relation, the abuser is categorized according to the relationship of the victim from the closest to the farthest (in terms of the possibility to put the victim under authority). With regard to this, the first category is relatives (father, sipling, cousin, step-father, etc.) while second category is acquiaintants including neighbors, educators, and friends. The last category includes strangers. In this study, the abusers are mostly relatives, but there are also strangers in a close ratio.

According to crime scene analyses reports, the abuses mostly took place in the perpetrator's home or in a place under the authority of the perpetrator. The factor that determines the timing of the abuse is when the victim is vulnerable or when he/she is made vulnerable. In terms of timing, it is seen that the perpetrator becomes physically closest to the victim as soon as the victim is vulnerable.

A significant proportion of the victims reported the psychological problems they experienced due to the abuse they were exposed to. These are generally distress, anxiety, dropping out of school, decline in school success, sleeping disorders, having nightmares, pessimism, eating disorders, constant fear, embarrassment, anger, menstrual irregularity, interest in sexual matters which is not parallel to his/her developmental stage, pervert attitudes, the feeling of constant hiding, pretending to be older than his/ her peers, feeling insecurity towards the external environment, feeling that they hurt me, feeling helpless, fighting, committing crime, substance use, suicidal behaviours and running away

\begin{tabular}{|c|c|}
\hline Stage 1 & One hundred seventy-five were pulled and deidentified. \\
\hline Stage 2 & $\begin{array}{l}\text { Each expert took } 20 \text { statements randomly and } \\
\text { determined main and subcategories. }\end{array}$ \\
\hline Stage 3 & $\begin{array}{l}\text { Experts compared and discussed the categories, then } \\
\text { determined a codebook. }\end{array}$ \\
\hline Stage 4 & $\begin{array}{l}\text { Experts re-coded first } 20 \text { statements according to the } \\
\text { codebook. }\end{array}$ \\
\hline Stage 5 & $\begin{array}{l}\text { Then experts were together and discussed categories } \\
\text { lastly. They reached a consensus on codebook (85\%). }\end{array}$ \\
\hline Stage 6 & $\begin{array}{l}\text { The author analysed all statements of sample according } \\
\text { to codebook consensused. }\end{array}$ \\
\hline
\end{tabular}

from home. The changes and reactions that the victims describe here are the phenomena they define by themselves, and not those diagnosed medically or psychiatrically.

\section{Parents' Behaviours}

The average age of the parents is 40 . Considering their educational status, $8.4 \%$ of them are illiterate while $53 \%$ are primary school graduates. $94.4 \%$ of them live with their children. In the investigation of sexual abuse cases as required by the Criminal Procedure code, the reports $(n=173)$ of the victims' parents or guardians are received as complainants. The sample of this study consists of the victims' mothers mostly ( $n=118$ ). The majority of the complainants learned that their child was the victim of abuse during the investigation. The general opinion of the majority of these people about the child is negative. Considering this negativity, there are statements that the mother-child relationship is not often good and that their children are victims of bad friends. Half of the complainants stated that they did not know the abuser at all. When looking at the reactions given immediately after learning the abuse, the majority of the complainants believe in their child and go to the police to initiate judicial processes. However, approximately one fifth of them do not believe in the abuse. Also, they report they would know this if it happened, and they think his/her child was lying by considering the fact that the alleged person would not do such a thing, etc.

\section{Abusers' Behaviours Pre and Post Abuse}

The average age of the abusers is 35.1. While only $0.5 \%$ of them are illiterate, $70.2 \%$ are at most primary school graduates. While $17 \%$ of them are unemployed and $4 \%$ are retired, the rest of them generally have a certain job. According to the victim reports in this study, the process that victims experience with abusers has three stages. Abusive behaviors are categorized as approaching the child, becoming physically closest to the child, and preventing disclosure of the abuse.

The approaching processes towards children (Grooming-I): Abusers have three ways of approaching children. "Deception" is the process of manipulating the abusive friendship, kinship, intimacy or relationship for sexual orientation by means of making promises or deceiving the child (for example: We get married anyway etc.). Also, abusers can make use of inducements (words, gift, food, money, etc.) to isolate the victim from his/her environment (for example: Look! There are other CDs at the back of the shop that you might like...) and approach the victim. At that point, it is possible to approach the child step by step without frightening the victim by means of distracting his/her attention. In their reports, the victims mostly stated that the abuser made them believe in him/her and gained his/her trust by the trickery methods (words, gift, food, money, etc.) he/she used. The second way is related to abusers' taking advantage of the opportunity 
as a result of children's vulnerability. The abuser looks for the opportunity to be alone with the victim and seizes the opportunity. Before the abuse, attention is paid to the moments when and environments where the victim is alone and the abuse behavior occurs as soon as the opportunity comes out. The last way is approaching children by threat and coercion. All of three ways help abusers to approach children physically and thus, abusers begin to gain acess to children (Table 2).

Getting physically closest to the child (Grooming-II): Before the abuse, when looking at the behavior of the abuser, at this stage, the abuser is physically close to the victim, may gain access to the child, and wants to be closest to the victim in order to commit the abuse. In the process of becoming physically closest to the child, the abuser becomes closest to the child by acting strategically or by forcing him/her. Approximately $60 \%$ of the abusers become closest to the child by following a step-by-step method. These include spending time with the child, playing games, behaviors that will erode the child (showing porn films or materials, wearing clothes to show his/her sexual organ to the child, etc.), and doing activities involving touching with children (wrestling, accidentally touching the child's genitals, etc.) If the child is uncomfortable because of the behaviours, he/she says, "I was kidding. When you grow up, you will do it like this. There is nothing to it...". Thus, the child gradually becomes unable to react (desensitised). After this stage, the act of abuse takes place. Within the framework of this description, the idea that abusers act strategically has been formed. Another method of getting closer is approaching directly the child by threat and coercion. Just before the abuse, it is seen that coercion and threats are used to ensure the child's full control and obedience. Strategic or coercive methods ensure that the abuser gets closest to the child. Only $20 \%$ of the children who reached to this point were able to escape from the abusers. The rest were exposed to abuse (Table 2).

Behaviors to prevent disclosure of abuse: After the abuse has occured, immediately after the act, the abuser tries to prevent the victim from disclosing the abuse by threatening, warning and bribery, and ensures that the child is re-abused. Among these, the threat of harming a loved one or informing their parents is the most prominent. Again, most of the victims did not disclose the abuse they were exposed to after the abuse (Table 2).

\section{DISCUSSION}

This study aims to provide recommendations for the prevention of sexual abuse cases by presenting a general picture in terms of case-victim-parent and abuser. In this study, the rate of victims of girls is higher than boys. Studies on the risk of victimization have found that the risk of victimization among girls is 2 to 5 times higher compared to boys $(8,39,40)$. When looking at the average age of children, it is within the expected age ranges in the literature, but it is lower than the studies in our country. Kilıçoğlu (20) found the average age of the victims 13.1 while Akbas et al. (41) found 12.1. At that point, the findings of this study in terms of gender and age are in accordance with the related literature.

More cases of penetration abuse were found in this study. In general, cases with penetration content are less in the studies conducted in the field. In Kılıçoğlu (20) study $60 \%$ of the victims were touched, $10 \%$ of them were exposed to verbal abuse, 3.3\% of them were exposed to be taken photographs, $10 \%$ of them raped, $3.3 \%$ of them were subjected to oral penetration. Also, 3.3\% of them were exposed to anal penetration while $10 \%$ of them were subjected to vaginal penetration. However, in Doğan (39) and Sertdemir et al. (13) studies, the rate of penetration-related abuse was lower than that of non-penetration ones. At that point, this finding is not compatible with the relevant literature. The reason for the high incidence of penetration cases in this study is thought to be related to the fact that the Istanbul Juvenile Branch is a unit that carries out qualified abuse cases (such as cases involving penetration).

The findings of the present study are consistent with the related literature in that the abusers are predominantly from the known people by the victim. The rate of foreigners in this study is slightly higher than the rate in the relevant literature. According to the study conducted by Kılıçoğlu (20) on this subject, when looking at the degree of closeness of the abusers to the victim, it was seen that $56.7 \%$ of the abusers were from the relatives or acquaintances of the victim, and $43.3 \%$ were people whom the victim did not know. When looked at the familiar circle of the victim, it was found that $3.3 \%$ of them were step-fathers and $53.3 \%$ of them were the victim's friends, relatives or neighbors. In Finkelhore (8) studies, it was found that the abuser was a friend or an acquaintance of the child with probability of $31-71 \%$. Also, it was shown that he was a family member with the probability of $14-43 \%$, and the rate of being abused by a foreigner was $22 \%$. These findings have shown similiarity with the rates in this study.

In this study, almost all of the victims generally experience some psychological problems due to the abuse they have been exposed to. A significant proportion of them attempted suicide or ran away from home and faced more with the negative sides of the outside world. In this regard, it is seen that children experience a wide variety of psychological problems due to the abuse they have been exposed to.

In the review article in which Kendall-Tackett et al. (42) examined 45 studies, it was reported that about $64-79 \%$ of sexual abuse victims showed psychiatric symptoms. These symptoms are post traumatic stress disorder, low self- 


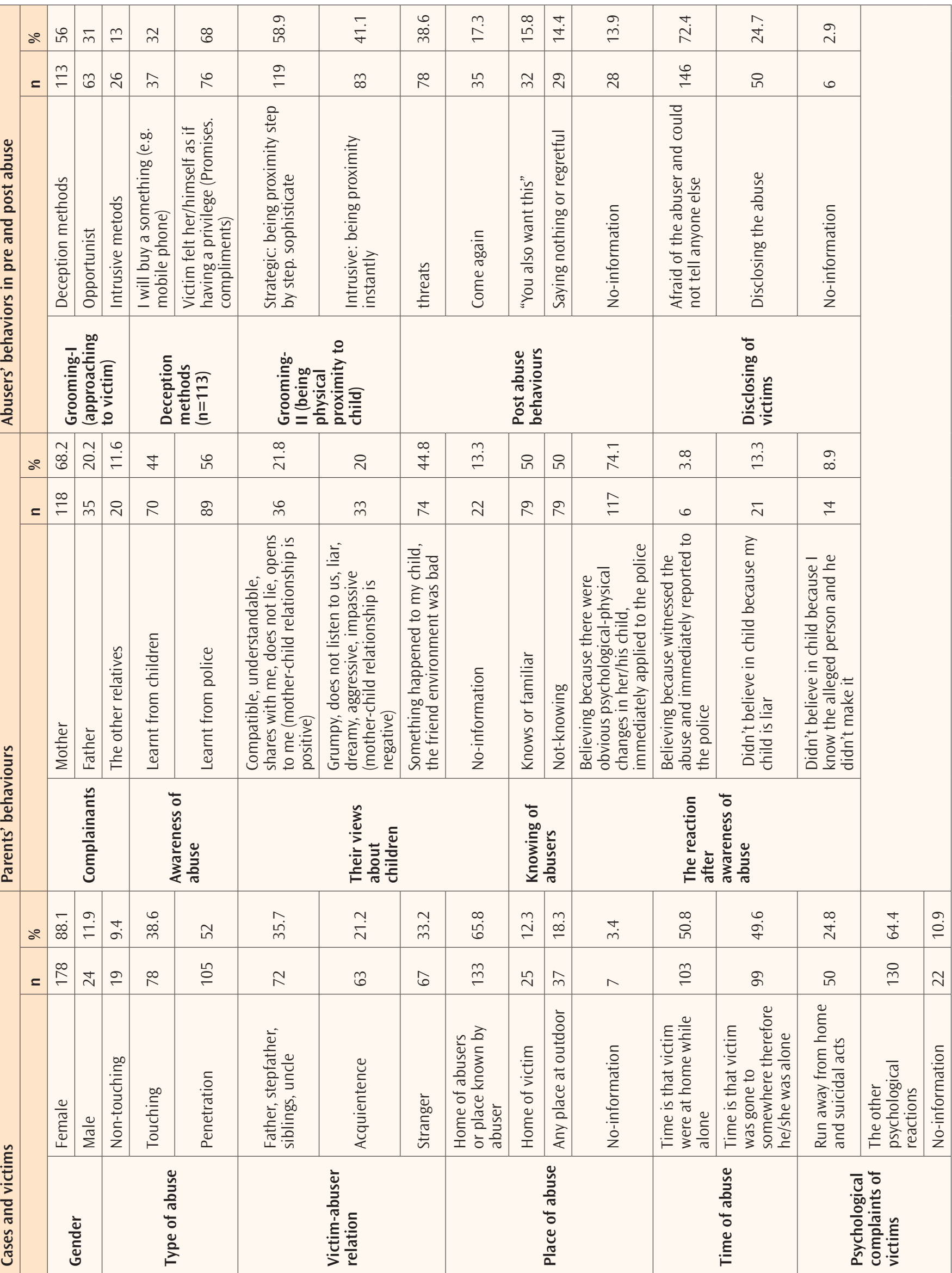


esteem, anxiety, fear, depression, suicidal thoughts, somatic complaints, aggressive behaviors, running away from home, and substance abuse respectively. In Doğan (39) study, it was also found that $81 \%$ of the victims that were examined had a psychiatric diagnosis and that conditions such as anxiety and substance addiction were observed at various rates in those who were diagnosed. In Tunç (19) study, eating disorders were found among children who were the victims of abuse. In a study conducted by Kılıçoğlu (20) on children who are victims of sexual abuse, $33.3 \%$ of the victims accused themselves of abuse, $27.7 \%$ of them had difficulty and were not willing to establish relationships with people they did not know, and $36.7 \%$ of them had suicidal thoughts. Also, it was observed that $3.3 \%$ of victims attempted suicide and $10 \%$ of them showed somatic complaints. As can be seen, the findings are in compatible with the relevant literature.

Parents' attitudes in sexual abuse cases play a cricual role in both effective investigation of the cases and the protection of the children. In this study, it is seen that this group generally includes mothers. Mothers are closest to children in this age group. However, even though the parents in the sample of this study stated that they supported their child by applying to the relevant units after learning about the abuse, it was observed that the child was not believed or supported at a significant rate. This is thought to be due to the negative definition of the mother-child relationship and the fact that parents have incomplete or incorrect information about abusers. In Akgün and Çetin (43), it was observed that the parents were in an authoritarian mood and the awareness level of abuse was found at a medium level. In the studies conducted on parents' belief in children's reports of abuse, a significant proportion of mothers did not believe the child's allegations, especially about incest relationship, and responded with accusationrejection (20). The reasons lying behind this were the negative mother-child relationship, the absence of physical findingswitnesses, and the perception that familiar people would not do such a thing. At that point, the findings of present study show parallesim with the related literature. This finding implies that in cases of sexual abuse, some supportive interventions (counseling, children's reactions after abuse, information about sexual abuse and abusers, etc.) should be given together with the investigation process, if necessary, for the parents as well as the child.

According to the present study, abusers tried many methods, from deceiving to threats, in order to approach children. When considered in terms of abusive behaviors, it was observed that the critical point was related to the child being "vulnerable". Victims are exposed to abuse when they are either vulnerable at the time or being made vulnerable by some promises, tricks, manipulations, threats and intimidation. In this process, prosocial activities such as spending time and taking care of the child are seen and thus, the child begins to trust in the abuser. Timing and the choice of location are significant factors in the vulnerability of children because the child's vulnerability is being guarded or created, and for this purpose the child is taken from the place where it is safe to the place where it is not safe forcibly or in a deceived way. Thus, the child becomes isolated at that moment in that place, which makes him/her vulnerable. In studies carried out in the field, abusers also spend time with the child (32), give gifts and money to the child (30). Thus, they ensure the child to come to the place they want and gain the child's trust and become closer with the child.

The second critical point in abusive behaviors is the processes of getting physically closest to the victim (step-by-stepstrategic or coercive). At that point, the physical closeness of the child with the abuser helps the child to be taken under control for abuse and become obedient since the act of abuse comes immediately after this process. In a study conducted by Kaufman et al. (30), abusers become closest to children by following certain strategies or using methods such as bribery and threats by coercion. The benefit of this type of threat to abusers is that it leads the victims to submit to the process of containment and to allow him or her for the disturbing touch. If the benefit or threat is not successful, then the abuser resorts to physical coercion. According to Elliot and Briere (27) study, if the victim resists, $61 \%$ of the abusers stop; however, some (39\%) go on by using threats and physical coercion to complete the abuse. In the present study, a small proportion of the victims who reached to this point were able to escape from abuse.

The third critical point is the use of methods such as warning, threat and bribery to prevent the child from disclosing. In the studies conducted in the field, a significant majority of the abusers resorted to threats and bribery in order to make the child not disclose it after the abuse (32). In this regard, the findings of the present study in terms of abusive behaviors are very similar to the relevant literature. Taken into consideration this finding, the following can be said for the abusers in this study conducted especifically for our country: Abusers are flexible, agile, sophisticated and capable of using any methods of reaching the child, like the abusers in the studies conducted in the US and other Anglo-Saxon countries. Therefore, professionals and child protectors need to consider this point both in prevention and investigation processes.

\section{Study Limitations}

This study has some limitations. The primary purpose is to collect evidence in statements and reports. For this reason, micro, mezzo and macro conditions that may lead victims to be abused should be studied separately. In addition, future studies should be conducted with the abusers and the victims themselves, following ethical processes, and compared with the findings presented in this study. 


\section{CONCLUSION}

To conclude, when the findings of this study are evaluated in a holistic manner at the level of victim, case, parent and abuser, it is seen that children who are victims of sexual abuse are quite vulnerable due to some conditions before and after the abuse. In summary, these are;

1- Physiological and mental disadvantages of the victims due to the developmental stage (age) at which they are,

2- The ability by which the victims can turn abusers' vulnerability into an opportunity immediately or being isolated immediately before the abuse at a place where they are not safe by means of some methods (tricking, threatening, etc.),

3- The advantageous positions that enable the abusers to come closer to the children step by step or by means of using coercive methods (being able to force them by strategic approaches or by threats and coercion),

4- Parents' inability to be aware of the abuse and problematic relationship situations. It has been observed that these are important factors for the children in our sample to be victims of abuse.

This vulnerability is considered to cause them to be dragged into an act of abuse and then prevent them from disclosing the abuse they experienced. The conditions leading to the vulnerability have been evaluated as a whole and defined as the "sexual abuse whirlpool" (Figure 1). The sexual abuse whirlpool becomes an important handicap for children in the process of disclosing the abuse they have experienced. At that point, another important outcome of this study is the psychological reactions and complaints reported by children due to the abuse. The child, who cannot report the abuse she/he has experienced due to the whirlpool she/he is in, actually gives some behavioral reactions and actually "disclose implicitly" them.

In this case, it is thought that if these implicit disclosure ways (the decline in children's success at school, running away from

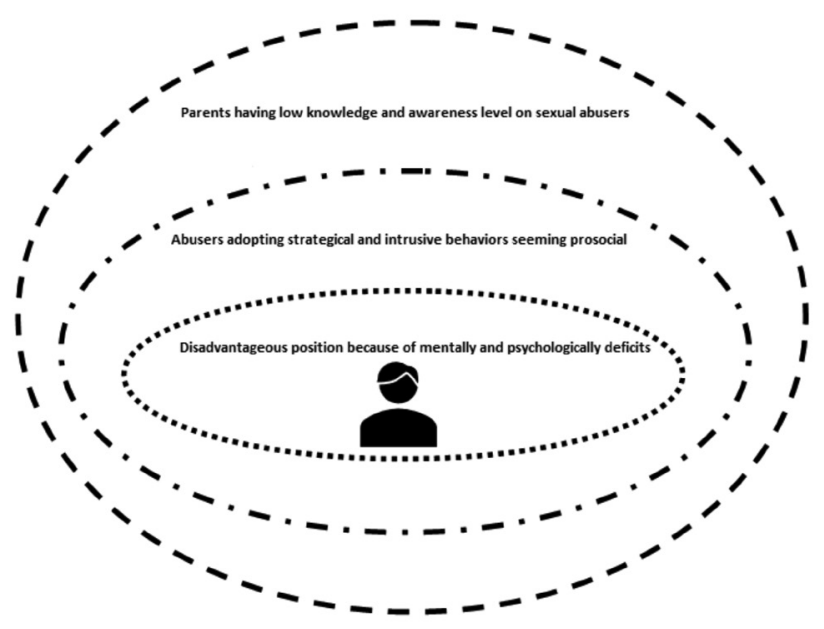

Figure 1. Sexual abuse whirlpool home, suicide attempts, psychosomatic reactions, insecurity, etc.) can be realized by parents and teachers, the possibility of children being rescued from this whirlpool will increase. At that point, the followings are recommended:

1- According to the developmental stages of children, children should get education related to adults' disturbing behaviors towards children and bad touch, and their knowledge and awareness should be increased.

2- Parents and teachers in the role of child protectors should be provided with education, seminars, counseling and social media applications regarding sexual abuse, sexual abusers and their grooming methods, and common beliefs and myths about sexual abuse (e.g., misperception that abusers are outsiders, etc.), in order to increase their knowledge and awareness on these issues. In addition, these practices should be made at the first time the abuse has been come to light.

3- Investigators should be trained on how abusers approach children. Thus, the level of education on what kind of criminals they face with should be increased.

4- Deterrent laws, which have already been implemented in countries such as the UK, prohibiting foreigners from approaching and touching children without justification should be enacted and implemented.

\section{ETHICS}

Ethics Committee Approval: For this study, permission was gotten from the Clinical Research Ethics Committee of the Faculty of Medicine at Istanbul University with the letter dated 05.07.2012 and numbered 18963, and the criteria for the Helsinki Declaration were taken into consideration.

*This study was prepared by rearrangement of the doctorate's thesis by Burak M. Gonultas, entitled as "The Examination of Common Features of Suspects' Expressions and the Construction of Sexual Violence Cases against Children".

Peer-review: Internally peer-reviewed.

Financial Disclosure: The author declared that this study received no financial support.

\section{REFERENCES}

1. Öztop DB, Özcan ÖÖ. The sociodemographic and clinical evaluation of sexually abused children. New Symposium. 2010;48:270-276.

2. Gönültaș MB. Çocuklara yönelik cinsel istismar sorușturmalarında mağdur bildirimlerinin önemi. Journal of Academic Social Sciences. 2016;4(23):274289.

3. Cohen L, Galynker I. Clinical Features of pedophilia and implications for treatment. J Psychiatr Pract. 2002;8(5):276-289.

4. Ibiloğlu A0, Atlı A, Oto R, Özkan M. Ensest ve çocukluk çă̆ı cinsel istismarı. içinde Tamam L, editör. Şiddet ve Travmaya Psikiyatrik Bakış. Ankara: Akademisyen Kitabevi; p. 99-117.

5. Plummer M. Lived experiences of grooming among australian male survivors of child sexual abuse. J Interpers Violence. 2018;33(1):37-63.

6. Walrath C, Ybarra M, Holden EW. Children with reported histories of sexual abuse: utilizing multiple perspectives to understand clinical and psychosocial profiles. Child Abuse Negl. 2003;27(5):509-524. 
7. Alikasifoğlu M, Erginöz E, Ercan O, Albayrak-Kaymak D, Uysal O, IIlter O. Sexual abuse among female high school students in Istanbul-Turkey. Child Abuse Negl. 2006;30(3):247-255.

8. Finkelhore D. Epidemiological factors in the clinical identification of child sexual abuse. Child Abuse Neglect. 1993;17(1):67-70.

9. U.S. Department of Health and Human Services. Child maltreatment 1996 reports from the states to the national child abuse and neglect data system. Washington DC:US Government Printing Office; 1998

10. Finkelhore D. Boys as victims: a review of the evidence, Child Sexual Abuse: New theory and research. New York: The Free Press; 1984, p. 150-171.

11. Güneș-Aslan G. Türkiye'de adli değerlendirmeden geçen çocuğa yönelik cinsel istismar vakaları hakkında bir değerlendirme. Elektronik Sosyal Bilimler Dergisi. 2020;19(73):48-68.

12. Yalçınkaya A. Kartal ilçesinde çocukta cinsel istismar olgularının değerlendirilmesi (Yüksek Lisans Tezi). İstanbul: Marmara Üniversitesi; 200.

13. Sertdemir M, Kurt B, Demirci Ş, Akça ÖF, Erden S, Uğuz, F, et al. Retrospective analysis of sociodemographic and clinical characteristics of forensic cases evaluated in a child and adolescent psychiatry clinic in Konya. Turk J Child Adolesc Ment Health. 2020;27(1):27-32.

14. Chen J, Dunne MP, Han P. Child sexual abuse in Henan province, China: associations with sadness, suicidality, and risk behaviors among adolescent girls. J Adolesc Health. 2006;38(5):544-549.

15. Syengo-Mutisya CM, Kathuku DM, Ndetei DM. Psychiatric morbidity among sexually abused children and adolescents. East Afr Med J. 2008;85(2):85-91.

16. Pinera-Lucatero AG, Trujillo-Hernandez B, Millan-Guerrero RO, Vasquez C. Prevalence of childhood sexual abuse among mexican adolescents. Child Care Health Dev. 2008;35(2):184-189.

17. Edinburgh L, Saewyc E, Levitt C. Gender differences in extrafamilial sexual abuse experiences among young teens. J Sch Nurs. 2006;22(5):278-284.

18. Doğangün B, Gönültaş BM, Uzun-Oğuz E, Oral G, Öztürk M. Psychological complaints reported by sexually abused children during crimina investigations: Istanbul example. Child Abuse Negl. 2016;56:54-61.

19. Tunç P. An investigation of the moderator role of parental bonding in the relationship between childhood trauma and Impaired eating attitudes. Turk J Child Adolesc Ment Health. 2020;27(2):75-84.

20. Kılıçoğlu AG. Cinsel istismar mağduru cocuk ve ergenlerin travmaya tepkileri ile anne-babalarının tepkilerinin karșııkı incelenmesi [Uzmanlık Tezi]. Bursa: Uludağ Üniversitesi Tıp Fakültesi; 2010, p. 180.

21. Avcı A, Tahiroğlu AY. Cinsel istismar, Çocuk ve Ergen Ruh Sağlığı ve Hastalıklar Içinde: Aysev A, Taner YI, editörler. İstanbul: Golden Print; 2007, p.721-736.

22. Glaser D, Rutter M, Taylor E. Child sexual abuse, Rutter's Child and Adolescent Psychiatry. Oxford, UK: Blackwell Publishing; 2002, p. 340-358.

23. Ackard DM, Neumark-Sztainer D. Multiple sexual victimizations among adolescent boys and girls: prevalence and associations with eating behaviors and psychological Health. J Child Sex Abuse. 2003;12(1):17-37.

24. Jenny C. Medical issues in sexual abuse, The APSAC handbook on child maltreatment. In: Briere J, Berliner L, Bulkley JA, Jenny C, Reid T, editors. Thousand Oaks, CA: Sage Publications; 1996, p. 195-205.

25. Berliner L, Elliott DM. Sexual abuse of children, The APSAC handbook on child maltreatment, In: Briere J, Berliner L, Bulkley JA, Jenny C, Reid T, editors. Thousand Oaks, CA: Sage Publications; 1996, p. 51-71.
26. DeYoung M. Immediate maternal reactions to the disclosure or discovery of Incest. J Fam Violence. 1994;9(1):21-31.

27. Elliott DM, Briere J. Forensic sexual abuse evaluations of older children: disclosures and symptomatology. Behav Sci Law. 1994;12(3):261-277.

28. Van Gijn EL, Lamb ME. Alleged sex abuse victims' accounts of their abusers' modus operandi. Journal of Forensic Social Work. 2013;3(2):133-149.

29. McAlinden A. "Grooming" and the sexual abuse of children: Implications for sex offender assessment, treatment, and management. Sexual Offender Treatment. 2013;8(1):1-13.

30. Kaufman KL, Holmberg JK, Orts KA, McCrady FE, Rotzien AL, Daleiden EL, et al. Factors influencing sexual offenders' modus operandi: an examination of victim-offender relatedness and age. Child Maltreatment. 1998;3(4):349361.

31. Craven S, Brown S, Gilchrist E. Sexual grooming of children: review of literature and theoretical considerations. J Sex Aggress. 2006;12(3):287-299.

32. Smallbone S, Wortley R. Child sexual abuse in Queensland: gender characteristics and modus operandi. Brisbane QSLD: Queensland Crime Commission; 2000.

33. Noakes L, Wincup E. Criminological research: Understanding qualitative methods. London: Sage Publications; 2004.

34. Levitt HM, Bamberg M, Creswell JW, Frost DM, Josselson R, Suárez-Orozco C Journal article reporting standards for qualitative primary, qualitative metaanalytic, and mixed methods research in psychology: The APA Publications and Communications Board task force report. Am Psychol. 2018;73(1):26-46.

35. Guidelines for the evaluation of sexual abuse of children: subject review American Academy of Pediatrics Committee on child abuse and neglect. Pediatrics. 1999;103(1):186-191. Erratum in: Pediatrics 1999;103(5 Pt 1):1049.

36. McKee HA, Porter JE. The Ethics of Archival Research. College Composition and Communication: Research Methodologies. 2012;64:59-81.

37. Socio-Legal Studies Association (SLSA). Statement of Principles of Ethical Research Practice 2009. Available from: https://www.slsa.ac.uk/index.php/ ethics-statement.

38. Miles MB, Huberman AM. Qualitative data analysis: An expanded sourcebook. Thousand Oaks, CA: Sage Publications; 1994.

39. Doğan ÖÖ. Cinsel istismara uğrayan ergenlerde bireysel, ailesel ve istismara ait özelliklerin tanımlanarak, istismara uğrama ve psikiyatrik bozukluk oluşumu üzerine etkilerinin araștırılması: kontrollü bir çalışma [Uzmanlık Tezi]. İzmir: Dokuz Eylül Üniversitesi Tıp Fakültesi; 2009. p. 180.

40. Putnam F. Ten-year research update review: child sexual abuse. J Am Acad Child Adolesc Psychiatry. 2003;42(3):269-278.

41. Akbaș S, Turla A, Karabekiroğlu K. Cinsel istismara uğramış çocuklar. Adl Bilimler Dergisi. 2009;8(1):24-32.

42. Kendall-Tackett KA, Williams LM, Finkelhor D. Impact of sexual abuse on children: a review and synthesis of recent empirical studies. Psychol Bull. 1993;113(1):164-180.

43. Akgün R, Çetin H. 4-6 yaş arası çocuğu olan ebeveyn tutumlarının ve istismar farkındalıklarının belirlenmesi üzerine bir çalıșma. Toplum ve Kültür Araștırmaları Dergisi. 2020;5:42-61. 